\title{
Effect of external and internal phosphate status on arsenic toxicity and accumulation in rice seedlings
}

\author{
WANG Lihong, DUAN Guilan* \\ Research Center for Eco-Environmental Sciences, Chinese Academy of Sciences, Beijing 100085, China. E-mail: lily2005_81@hotmail.com
}

Received 07 March 2008; revised 28 July 2008; accepted 06 August 2008

\begin{abstract}
Phosphorus (P) deficiency is thought to exacerbate the arsenic (As) phytotoxicity in paddy rice. The experiments were conducted to investigate the effects of external phosphate supply on As accumulation in rice and its toxicity under phosphate deficiency conditions. Rice seedlings pretreated with a phosphorus deficient nutrient solution $(-\mathrm{P})$ for $14 \mathrm{~d}$ accumulated more As than those pretreated with a normal phosphorus supply nutrient solution $(+\mathrm{P})$. Rice protreated with $-\mathrm{P}$ showed As toxicity symptoms after being exposed to $50 \mu \mathrm{mol} / \mathrm{L}$ arsenate for $4 \mathrm{~h}$, while $+\mathrm{P}$ rice did not show any toxicity symptoms. Arsenic toxicity symptoms can be alleviated by increasing external $\mathrm{P}$ concentrations. The arsenate uptake rate and accumulation corresponded with the As toxicity in rice plants. Arsenic concentrations in rice roots decreased with increasing external phosphate concentrations. The lowest As accumulation and the highest $\mathrm{P}$ accumulation were found when the external $\mathrm{P}$ concentration reached $100 \mu \mathrm{mol} / \mathrm{L}$. In short, $\mathrm{P}$ deficiency increased the sensitivity of rice to arsenate and increasing of external phosphate supply could alleviate As toxicity.
\end{abstract}

Key words: phosphorus; arsenate; arsenic toxicity; arsenic accumulation; rice seedlings

DOI: $10.1016 /$ S1001-0742(08)62275-5

\section{Introduction}

Arsenic (As) is one of the worst cancer-causing chemicals which widely distributes in the environment from both natural and anthropogenic sources. Human beings can be exposed to As through their occupation, drinking water, and diet (ATSDR, 1993). The highest concentration of As was found in the seafood, followed by rice and rice products (Tao and Bolger, 1998). Rice is the staple food for the majority of population in South East Asia where has been found to have high levels of As in groundwater and soils. In large areas of Bangladesh, West Bengal and India, As-contaminated groundwater is usually used for irrigation of paddy soils (Abedin et al., 2002; Chen et al., 2004). In a typical Bangladeshi diet, it is estimated that rice can be a significant dietary source of inorganic As (Williams et al., 2005, 2006). Therefore, rice As contamination is a serious problem, and it is urgent to develop strategies for minimizing As accumulation and toxicity in rice plants.

In contrast, as the chemical analogue of As, phosphorus (P) is one of 17 essential elements required for plant growth. However, $\mathrm{P}$ is frequently the most limiting element for plant growth and development. Crop yield on 30\%$40 \%$ of the world's arable land is limited by $\mathrm{P}$ availability (Runge-Metzger, 1995; von Uexküll and Mutert, 1995). And, about $67 \%$ of the farm land in China was shown to be serious $\mathrm{P}$ deficient for crop growth. In addition, $\mathrm{P}$ is

\footnotetext{
* Corresponding author. E-mail: duangl@ rcees.ac.cn
}

low bioavailable because it rapidly transforms to insoluble complexes with cations, particularly with aluminum and iron under acid conditions (Vance et al., 2003). Thus, $\mathrm{P}$ fertilization is the common agriculture strategy to improve crop yield, especially for rice. At present, 12 Asian countries have reported high As levels in part of their groundwater resources. Often these resources are used to irrigate paddy soil (Heikens, 2006). Therefore, it is important to understand As uptake and accumulation by rice plants when $\mathrm{P}$ fertilizer is supplied after $\mathrm{P}$ starvation.

Arsenate, the oxidized inorganic form of As, is taken up and translocated via the phosphate transporter systems (Asher and Reay, 1979; Lee, 1982; Ullrich-Eberius et al., 1989; Meharg and Macnair, 1992). The competition of uptake and translocation between phosphate and arsenate was shown in lots of plants (Chen et al., 2004; Liu et al., 2004; Rosa et al., 2006). Over-accumulation of shoot $\mathrm{P}$ is one of the mechanisms of plants to increase arsenate resistance. Kobayashi et al. (2005) used arsenatesensitive and arsenate resistance mutants of the green alga to investigate the relationship between $\mathrm{P}$ accumulation and As resistance. They found that arsenate-resistance mutants had higher $\mathrm{P}$ contents than wild type and arsenate-sensitive mutants (Kobayashi et al., 2005). The similar result was found using the Arabidopsis ars 1 mutant (Lee et al., 2003). Furthermore, maintaining a greater ratio of $\mathrm{P} / \mathrm{As}$ in the roots may also be one of the reasons for the high As tolerance of the hyperaccumulator Pteris vittata (Singh 
and Ma, 2006). These results confirmed that plant internal $\mathrm{P}$ status affect arsenate resistance. Fayiga et al. (2008) showed that it was possible to optimize plant As removal by adjusting nutrients in the growth medium. Phosphorusfertilizer increased As uptake in $P$. calomelanos and $P$. vittata, which can be used as a cost-effective amendment for As polluted soils (Jankong et al., 2007; Fayiga and Ma, 2006). However, so far, no experimental data have shown the effects of external fertilization on As uptake and accumulation by rice plants after $\mathrm{P}$ starvation.

In this study, experiments were conducted to investigate the effects of internal and external $\mathrm{P}$ on As resistance and As accumulation in rice seedlings. These results would provide some insights into the P-modulated As accumulation and toxicity in rice plants, and would be helpful in exploring $\mathrm{P}$ fertilization strategies for rice yield under the condition of both $\mathrm{P}$ deficiency and As contamination.

\section{Materials and methods}

\subsection{Plant materials}

Rice (Oryza sativa L. cv Jiahua 1) seeds were sterilized in $10 \% \mathrm{H}_{2} \mathrm{O}_{2}$ solution for $15 \mathrm{~min}$, then washed with de-ionized water. The seeds were germinated in moist perlite. After 3 weeks, uniform seedlings were transplanted to PVC pots $(7.5 \mathrm{~cm}$ diameter and a height of $14 \mathrm{~cm}$, one plant per pot) containing $500 \mathrm{~mL}$ nutrient solution, modified from Hewitt (1966). At the first week, $1 / 6$ strength macronutrient and 1/4 strength micronutrient solution was used, then, 1/3 strength macronutrient and $1 / 2$ strength micronutrient solution was used. Full-strength macronutrient composition was: $5.0 \mathrm{mmol} / \mathrm{L} \mathrm{NH}_{4} \mathrm{NO}_{3}$, $2.0 \mathrm{mmol} / \mathrm{L} \mathrm{K}_{2} \mathrm{SO}_{4}, 4.0 \mathrm{mmol} / \mathrm{L} \mathrm{CaCl}_{2}, 1.5 \mathrm{mmol} / \mathrm{L}$ $\mathrm{MgSO}_{4}, 1.3 \mathrm{mmol} / \mathrm{L} \mathrm{KH}_{2} \mathrm{PO}_{4}$, and micronutrient composition was: $50 \mathrm{mmol} / \mathrm{L} \mathrm{Fe}(\mathrm{II})-\mathrm{EDTA}, 10 \mathrm{mmol} / \mathrm{L} \mathrm{H}_{3} \mathrm{BO}_{4}$, $1.0 \mu \mathrm{mol} / \mathrm{L} \mathrm{ZnSO}_{4} \cdot 7 \mathrm{H}_{2} \mathrm{O}, 1.0 \mu \mathrm{mol} / \mathrm{L} \mathrm{CuSO}_{4} \cdot 5 \mathrm{H}_{2} \mathrm{O}, 5.0$ $\mu \mathrm{mol} / \mathrm{L} \quad \mathrm{MnSO}_{4} \cdot \mathrm{H}_{2} \mathrm{O}, 0.5 \mu \mathrm{mol} / \mathrm{L} \quad \mathrm{Na}_{2} \mathrm{MoO}_{4} \cdot 2 \mathrm{H}_{2} \mathrm{O}, 0.2$ $\mu \mathrm{mol} / \mathrm{L} \mathrm{CoSO}_{4} \cdot 7 \mathrm{H}_{2} \mathrm{O}$. The nutrient solution was renewed every $2 \mathrm{~d}$ and the $\mathrm{pH}$ was adjusted to 5.6 with $\mathrm{KOH}$ or $\mathrm{HCl}$. The plants were grown in a growth room at a 14-h light period $\left(260-350 \mu \mathrm{E} /\left(\mathrm{m}^{2} \cdot \mathrm{s}\right) ; 28^{\circ} \mathrm{C} / 20^{\circ} \mathrm{C}\right.$ of day/night; $60 \%$ relative humidity). All the experiments were carried out with three replicates.

\subsection{Effect of internal $P$ status on As accumulation in rice seedlings}

For this experiment, 6 pots of 7-week-old rice plants were selected. To get different internal $P$ status, 3 pots were grown in normal nutrient solution, 3 pots were pretreated with $\mathrm{P}$-free $(-\mathrm{P})$ nutrient solution $(\mathrm{KCl}$ was added instead of $\mathrm{KH}_{2} \mathrm{PO}_{4}$ to compensate for the reduction in potassium concentration). After $14 \mathrm{~d}$ growing, all plants were exposed to $50 \mu \mathrm{mol} / \mathrm{L}$ arsenate in $-\mathrm{P}$ nutrient solution for $24 \mathrm{~h}$. When the plants were harvested, they were thoroughly washed with tap water, and then with de-ionized water, adhering water was then removed with filter paper. Root and shoot of each plant was separated and oven-dried at $70^{\circ} \mathrm{C}$ for $2 \mathrm{~d}$, and dry weight was determined.

\subsection{Effect of external $P$ concentrations on As toxicity in rice seedlings}

In this experiment, 12 pots of 7-week-old rice seedlings were selected. Rice seedlings were exposed to P-free (-P) nutrient solution for $14 \mathrm{~d}$, and then were treated with 50 $\mu \mathrm{mol} / \mathrm{L}$ arsenate and re-supplied with different phosphate concentrations $(0,25,50,100 \mu \mathrm{mol} / \mathrm{L})$ at the same time. After $24 \mathrm{~h}$, the plants were harvested as described above.

\subsection{As and $P$ uptake curves under different external $P$ concentrations}

Rice seedlings were pre-treated with -P nutrient solution for $14 \mathrm{~d}$, and then were exposed to $50 \mu \mathrm{mol} / \mathrm{L}$ arsenate with $0,25,50,100 \mu \mathrm{mol} / \mathrm{L}$ phosphate re-supplying, respectively, for $24 \mathrm{~h}$. The plant growth medium $1 \mathrm{~mL}$ was sampled for $\mathrm{P}$ and As analysis at time intervals of $0,1,2,3,4,6,8$, 10, 12, and $24 \mathrm{~h}$. Water losses through transpiration were compensated by the addition of de-ionized water at hourly intervals according to Zhao et al. (2002).

\subsection{Total As and $P$ concentrations analysis}

Oven-dried plant materials were digested in nitric acid on a heating block (Digestion Systems of AIM500, A. I. Scientific, Australia), and the temperature was at $100^{\circ} \mathrm{C}$ for $1 \mathrm{~h}$, then at $120^{\circ} \mathrm{C}$ for $60 \mathrm{~h}$. Reagent blank and standard reference (GBW07605, from the National Research Center for Standard Materials in China) were used to verify the precision of analytical procedures. The concentrations of As were measured by an atomic fluorescence spectrometry (AF-610A, Beijing Ruili Analytical Instrument Co., Beijing, China). The concentrations of $\mathrm{P}$ were measured by inductively coupled plasma optical emission spectrometer (ICP-OES, Optima 2000 DV, Perkin-Elmer, USA).

\subsection{Statistical analysis}

Analysis of variance (ANOVA) on concentrations of nutrients was performed using SPSS 11.5 for windows. Curve fitting was performed by using Sigma Plot 9.0 (Jandel Scientific, Erkrath, Germany).

\section{Results and discussion}

\subsection{Effect of internal $P$ status on As toxicity in rice seedlings}

The pre-experiment has shown that $\mathrm{P}$ deficiency for 14 $\mathrm{d}$ could decrease root and shoot $\mathrm{P}$ concentrations to 2.4 and $3.2 \mathrm{mg} / \mathrm{g}$, closed to P deficiency critical level (1.8-2.6 $\mathrm{mg} / \mathrm{g}$ ) determined by Fageria (1976) for rice. Therefore, the rice seedlings were pre-treated with $-\mathrm{P}$ and $+\mathrm{P}$ nutrient solutions for $14 \mathrm{~d}$, and then were exposed to $50 \mu \mathrm{mol} / \mathrm{L}$ arsenate in -P nutrient solutions for $24 \mathrm{~h}$.

As shown in Fig. 1a, $-\mathrm{P}$ pretreated rice plants accumulated more As than $+\mathrm{P}$ ones when exposed to $50 \mu \mathrm{mol} / \mathrm{L}$ arsenate in $-\mathrm{P}$ nutrient solution for $24 \mathrm{~h}$. Furthermore, $\mathrm{P}$ pretreated rice plants were more sensitive to arsenate than $+\mathrm{P}$ ones. The $-\mathrm{P}$ rice showed acute As toxicity symptoms after exposing to $50 \mu \mathrm{mol} / \mathrm{L}$ arsenate $4 \mathrm{~h}$, while $+\mathrm{P}$ pretreated rice did not show any As toxicity symptoms 

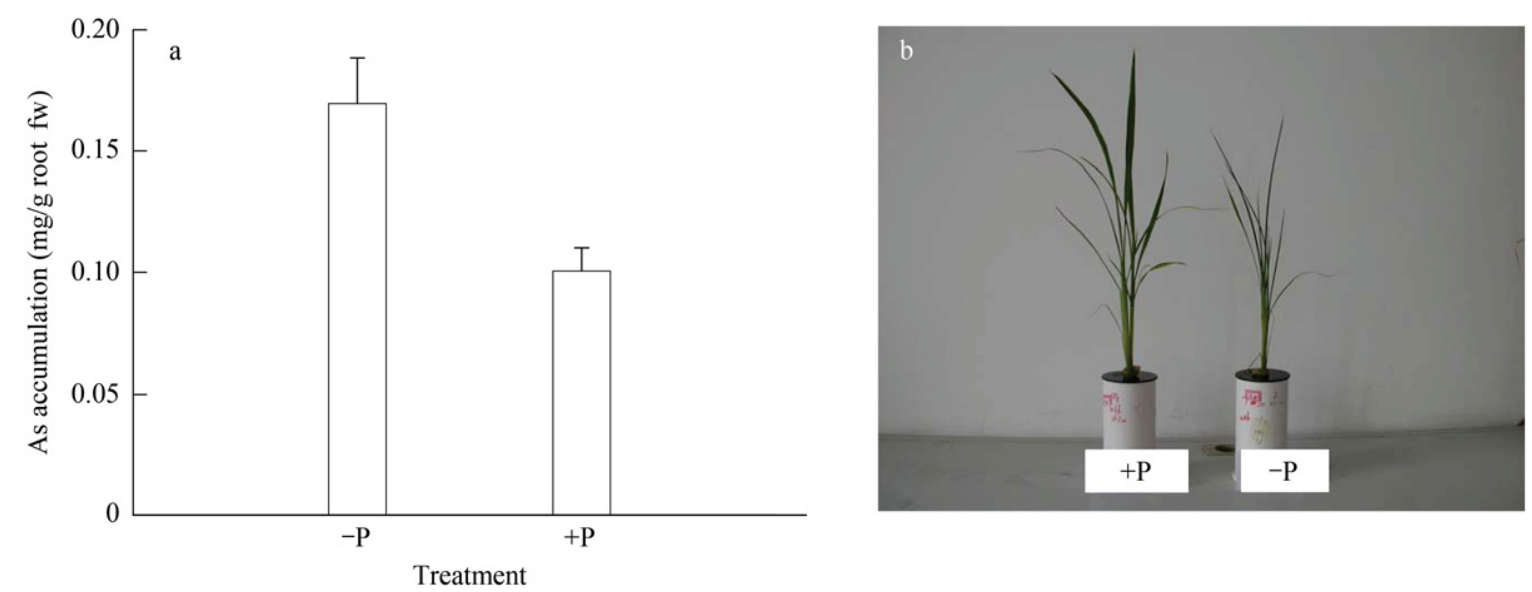

Fig. 1 Arsenic accumulation in rice seedlings (a) and arsenic toxicity symptoms of rice (b) after being pre-treated with $-\mathrm{P}$ and $+\mathrm{P}$ nutrient solution for $14 \mathrm{~d}$, and then exposed to $50 \mu \mathrm{mol} / \mathrm{L}$ arsenate for $24 \mathrm{~h}$ in $-\mathrm{P}$ nutrient solution. Data are means $\pm \mathrm{SE}(n=3)$.

after exposure $24 \mathrm{~h}$ (Fig. 1b). Geng et al. (2006) also reported that $9 \mathrm{~d} \mathrm{P}$-deprived rice showed acute As toxicity symptoms after exposed to $26.7 \mu \mathrm{mol} / \mathrm{L}$ arsenate $4 \mathrm{~h}$, while $+\mathrm{P}$ pre-treatment rice had no As toxicity symptoms. Arsenate is taken up via the phosphate transporter (Meharg and Macnair, 1992) and high-affinity phosphate transporter will be induced under phosphate deficiency conditions (Vance et al., 2003; Schachtman and Shin, 2007). Therefore, more arsenate was taken up through high-affinity phosphate transporter by -P pre-treated rice plants under phosphate deficiency conditions, and then showed acute As toxicity symptoms.

\subsection{External $P$ addition alleviated As toxicity of rice seedlings}

In order to find out whether increasing of external phosphate concentrations can alleviate As toxicity symptoms caused by As exposure under low internal $\mathrm{P}$ status, rice seedlings grew in $-\mathrm{P}$ nutrient solution for $14 \mathrm{~d}$ were exposed to $50 \mu \mathrm{mol} / \mathrm{L}$ arsenate with different phosphate concentrations in the nutrient solutions. Table 1 shows that there was no difference in dry weight of rice roots and shoots under different phosphate concentrations, while there was difference in fresh weight. Fresh weight of rice roots and shoots without phosphate supply was lower than the other treatments and the treatment with $100 \mu \mathrm{mol} / \mathrm{L}$ phosphate supply had the highest fresh weight in shoots (Table 1). These results corresponded with As toxicity symptoms in rice seedlings. Rice seedlings with 0,25 , and $50 \mu \mathrm{mol} / \mathrm{L}$ phosphate in nutrient solution showed As toxicity symptoms (leaves curled and losing water), while rice with $100 \mu \mathrm{mol} / \mathrm{L}$ phosphate supply did not show any toxicity symptoms (Fig. 2).

Arsenic concentrations were determined in rice plants with different external phosphate supply. Figure 3a shows that As concentrations in rice roots decreased significantly with increasing external $\mathrm{P}$ concentrations in nutrient solution, while As concentrations in rice shoots kept unchanged until external $\mathrm{P}$ concentration reached 100 $\mu \mathrm{mol} / \mathrm{L}$. Furthermore, As accumulation decreased significantly when external phosphate concentration reached 50 $\mu \mathrm{mol} / \mathrm{L}$ and $\mathrm{P}$ accumulation increased significantly when

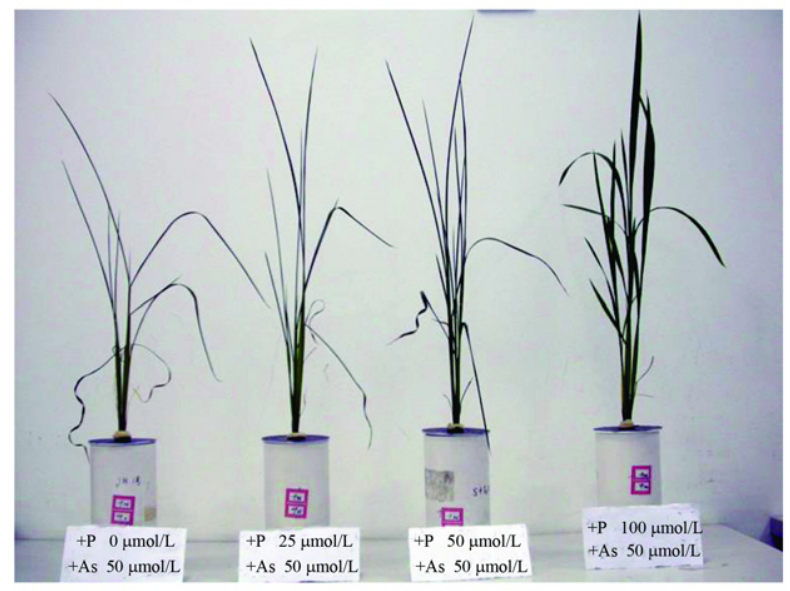

Fig. 2 Arsenic toxicity symptoms of rice which were pre-treated with $-\mathrm{P}$ nutrient solution for $14 \mathrm{~d}$, and then exposed to $50 \mu \mathrm{mol} / \mathrm{L}$ arsenate with $0,25,50$, and $100 \mu \mathrm{mol} / \mathrm{L}$ phosphate re-supplying, respectively.

Table 1 Dry and fresh weight of rice roots and shoots pre-treated with -P nutrient solution

\begin{tabular}{|c|c|c|c|c|c|}
\hline & & \multicolumn{4}{|c|}{ Treatment } \\
\hline & & $+\mathrm{P} 0 \mu \mathrm{mol} / \mathrm{L}$ & $+\mathrm{P} 25 \mu \mathrm{mol} / \mathrm{L}$ & $+\mathrm{P} 50 \mu \mathrm{mol} / \mathrm{L}$ & $+\mathrm{P} 100 \mu \mathrm{mol} / \mathrm{L}$ \\
\hline \multirow[t]{2}{*}{ Dry weight } & Root (g) & $0.22 \pm 0.03 \mathrm{a}$ & $0.26 \pm 0.01 \mathrm{a}$ & $0.23 \pm 0.01 \mathrm{a}$ & $0.24 \pm 0.03 \mathrm{a}$ \\
\hline & Shoot (g) & $0.72 \pm 0.02 \mathrm{a}$ & $0.78 \pm 0.03 \mathrm{a}$ & $0.81 \pm 0.06 \mathrm{a}$ & $0.81 \pm 0.09 \mathrm{a}$ \\
\hline \multirow[t]{2}{*}{ Fresh weight } & Root (g) & $2.13 \pm 0.10 \mathrm{a}$ & $2.72 \pm 0.16 \mathrm{a}$ & $2.48 \pm 0.16 \mathrm{a}$ & $2.71 \pm 0.31 \mathrm{a}$ \\
\hline & Shoot (g) & $2.40 \pm 0.12 b$ & $3.12 \pm 0.10 \mathrm{ab}$ & $3.54 \pm 0.32 \mathrm{ab}$ & $4.21 \pm 0.57 \mathrm{a}$ \\
\hline
\end{tabular}

The rice roots and shoots were pre-treated with $-\mathrm{P}$ nutrient solution for $14 \mathrm{~d}$, and then exposed to $50 \mu \mathrm{mol} / \mathrm{L}$ arsenate with $0,25,50$, and $100 \mu \mathrm{mol} / \mathrm{L}$ phosphate re-supplying, respectively.

Data are means \pm SE $(n=3)$, treatments with the different letter $(\mathrm{a}, \mathrm{b})$ are significantly different $(P<0.05)$. 
external phosphate concentration reached $100 \mu \mathrm{mol} / \mathrm{L}$ (Fig. 3b). These results support the observations that arsenate competes uptake transporter with phosphate and increasing of external phosphate can alleviate As toxicity (Abedin et al., 2002; Wang et al., 2002; Geng et al., 2005). However, P-fertilizer increased As uptake in $P$. calomelanos and P. vittata (Jankong et al., 2007; Fayiga and Ma, 2006). This result possibly caused by the enhanced mobility of As in the soil which occurred by the replacement of As by $\mathrm{P}$ from the soil binding site as a competitive anion exchange (Smith et al., 2002). Fitz and Wenzel (2002) have reported that the effects of $P$ on the uptake and toxicity of As in plants depended on plant species, chemical speciation of As, growth medium and the experimental conditions. Therefore, the difference between our result and Jankong's may be caused by different plant species and growth medium.

\subsection{Effect of external $P$ concentrations on As and $P$ uptake curves by rice seedlings}

Rice seedlings showed As toxicity symptoms at different time with different phosphate re-supplying when exposed to $50 \mu \mathrm{mol} / \mathrm{L}$ arsenate. In $-\mathrm{P}$ nutrient solutions, acute As toxicity symptoms (shoot curled) appeared after $4 \mathrm{~h}$ exposure; in $+\mathrm{P} 25$ and $+\mathrm{P} 50 \mu \mathrm{mol} / \mathrm{L}$ treatments, the toxicity symptoms were found after As exposure for 12 $\mathrm{h}$; and in $+\mathrm{P} 100 \mu \mathrm{mol} / \mathrm{L}$ treatment, no toxicity symptom was found after $24 \mathrm{~h}$ As exposure. These results indicate that external phosphate may affect As uptake speed as well as accumulation in rice plants. In order to identify this hypothesis, time-dependent As and $\mathrm{P}$ uptake rate was measured.

Figure $4 \mathrm{a}$ shows the cumulative uptake of arsenate, expressed on a basis of rice roots fresh weight. The rate of arsenate accumulation by roots decreased significantly with increasing of phosphate concentrations in the nutrient solution. In $+\mathrm{P} 0 \mu \mathrm{mol} / \mathrm{L}$ treatment, rice seedlings accumulated arsenate rapidly, at $4 \mathrm{~h}$, the curve reached the saturated point $(0.12 \mathrm{mg} / \mathrm{g}$ root $\mathrm{fw})$. In $+\mathrm{P} 25 \mu \mathrm{mol} / \mathrm{L}$ and $+\mathrm{P} 50 \mu \mathrm{mol} / \mathrm{L}$ treatments, rice seedlings accumulated arsenate slowly, at $12 \mathrm{~h}$, the curves reached the saturated point ( 0.16 and $0.12 \mathrm{mg} / \mathrm{g}$ root $\mathrm{fw}$, respectively). In $+\mathrm{P} 100$ $\mu \mathrm{mol} / \mathrm{L}$ treatment, arsenate accumulation rate was similar to $+\mathrm{P} 25$ and $+\mathrm{P} 50 \mu \mathrm{mol} / \mathrm{L}$ treatments, but $4 \mathrm{~h}$, the curve reached the saturated point $(0.05 \mathrm{mg} / \mathrm{g}$ root $\mathrm{fw})$. The As uptake rate had no significant difference between $+\mathrm{P} 0,25$, and $50 \mu \mathrm{mol} / \mathrm{L}$ treatments, while decreased significantly in $+\mathrm{P} 100 \mu \mathrm{mol} / \mathrm{L}$ treatment after $24 \mathrm{~h}$ arsenate exposure

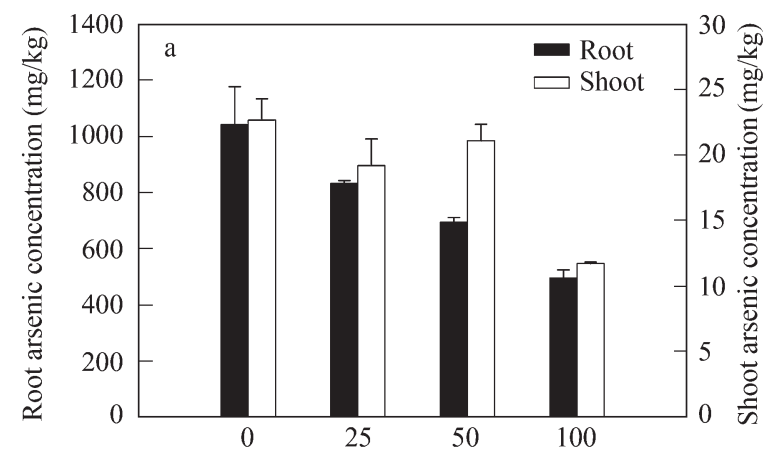

External $\mathrm{P}$ concentration in nutrient solution $(\mu \mathrm{mol} / \mathrm{L})$

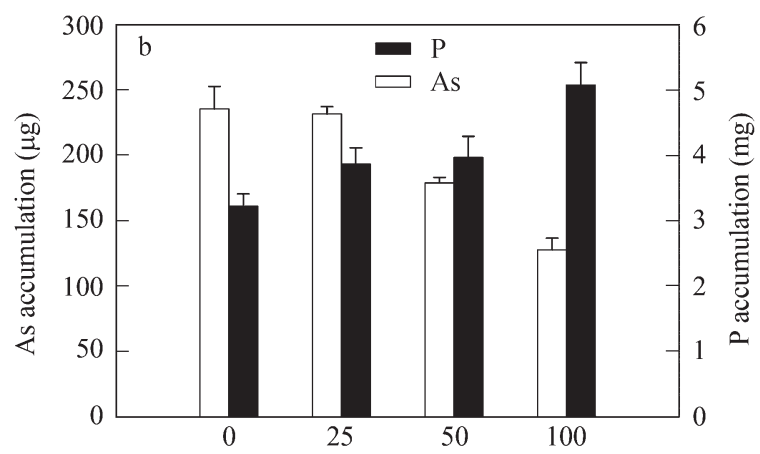

External P concentration in nutrient solution $(\mu \mathrm{mol} / \mathrm{L})$

Fig. 3 Arsenic concentrations in rice roots and shoots (a), and arsenic and phosphorus accumulation in the whole rice plants (b). The rice roots and shoots were pretreated with the same as in Table 1 . Data are means $\pm \operatorname{SE}(n=3)$.
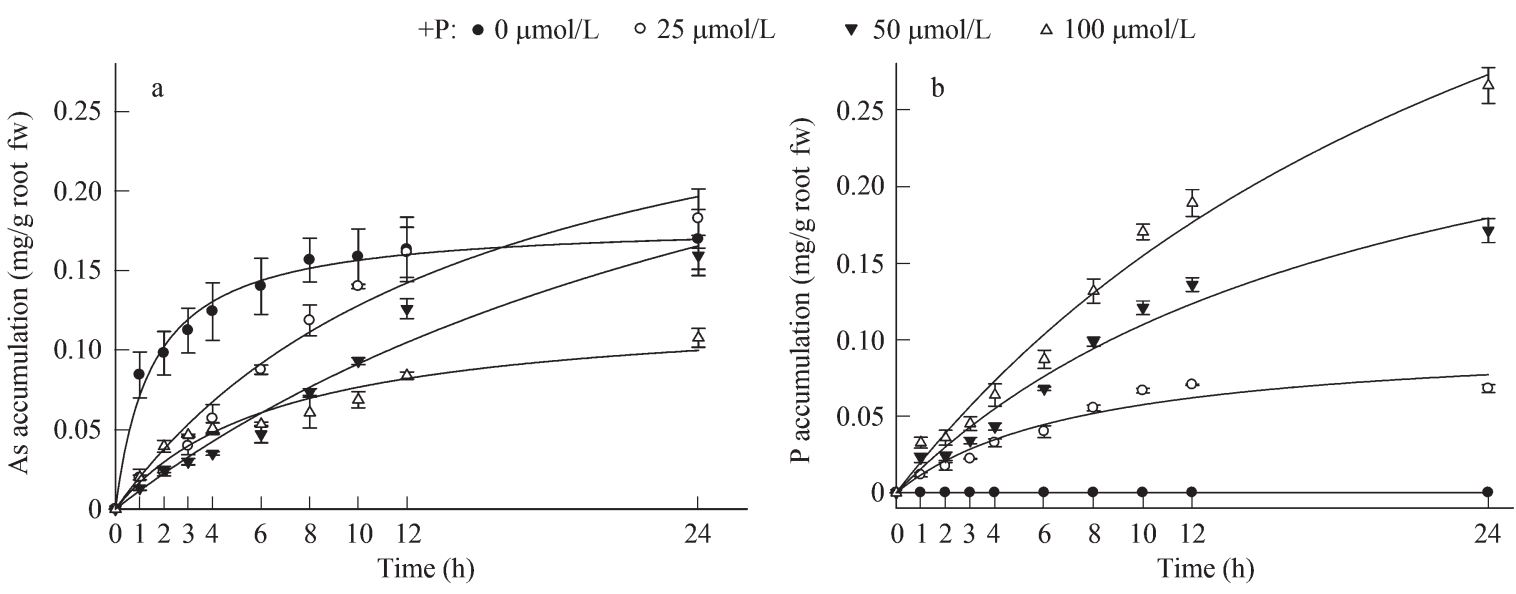

Fig. 4 Time-dependent arsenic (a), and phosphate (b) uptake curves of rice. The rice roots and shoots were pre-treated with the same as in Table 1. Data are means $\pm \operatorname{SE}(n=3)$. 
(Fig. 4a). These results were confirmed by As content in the whole rice plants (Fig. 3b). Arsenic content in $+\mathrm{P} 0$ $\mu \mathrm{mol} / \mathrm{L}$ and $+\mathrm{P} 25 \mu \mathrm{mol} / \mathrm{L}$ rice had no difference, while $+\mathrm{P}$ $100 \mu \mathrm{mol} / \mathrm{L}$ rice got the lowest As content. These results also corresponded with As toxicity symptoms (Fig. 2).

Figure $4 \mathrm{~b}$ shows the accumulation curves of phosphate in rice roots with different concentrations of phosphate supply. The rate of phosphate accumulation increased with increasing of external phosphate concentrations and was approximately linear $(R=0.991,0.995$, and 0.994 for $+\mathrm{P}$ 25,50 , and $100 \mu \mathrm{mol} / \mathrm{L}$ treatments, respectively) in the first $12 \mathrm{~h}$ (Fig. 4b). The uptake rate of $\mathrm{P}$ and As was compared when external $\mathrm{P}$ and As concentration was the same (50 $\mu \mathrm{mol} / \mathrm{L})$. The result showed that phosphate uptake rate was higher than As uptake rate. This result suggests that $\mathrm{P}$ possibly is preferentially taken up by $\mathrm{P} / \mathrm{As}$ transporters compared to its toxic analogue (Meharg and Macnair, 1994). Wang et al. (2002) also reported that phosphate had a higher affinity to the uptake system in $P$. vittata root than arsenate.

\section{Conclusions}

Rice seedlings with lower internal $\mathrm{P}$ status were more sensitive to arsenate. Increasing of external phosphate concentrations can alleviate As toxicity symptoms through decreasing uptake of arsenate and over-accumulation of internal $\mathrm{P}$.

\section{Acknowledgments}

This work was supported by the National Natural Science Foundation of China (No. 40671102, 20777083), the Knowledge Innovation Program of the Chinese Academy of Sciences (No. RCEES-QN-200702) and the Special Funds for Young Scholars of RCEES, CAS.

\section{References}

Abedin M J, Feldmann J, Meharg A A, 2002. Uptake kinetics of arsenic species in rice plants. Plant Physiology, 128(3): $1120-1128$.

Agency for Toxic Substances and Disease Registry (ATSDR), 1993. Toxicological profile for arsenic (Atlanta, GA: ATSDR). Atlanta, USA.

Asher C J, Reay P F, 1979. Arsenic uptake by barley seedlings. Australian Journal of Plant Physiology, 6: 459-466.

Chen Z, Zhu Y G, Liu W J, Meharg A A, 2004. Direct evidence showing the effect of root surface iron plaque on arsenite and arsenate uptake into rice (Oryza sativa) roots. New Phytologist, 165: 91-97.

Fageria N K, 1976. Critical level P, K, Ca and Mg contents in the tops of rice and peanut plants. Plant and Soil, 45: 421-431.

Fayiga A O, Ma L Q, 2006. Using phosphate rock to immobilize metals in soil and increase uptake by hyperaccumulator Pteris vittata. Science of the Total Environment, 359: 1725.

Fayiga A O, Ma L Q, Rathinasabapathi B, 2008. Effects of nutrients on arsenic accumulation by arsenic hyperaccumulator Pteris vittata L. Environmental and Experimental Botany, 62: 231-237.
Fitz W J, Wenzel W W, 2002. Arsenic transformations in the soil rhizosphere-plant system: Fundamentals and potential application to phytoremediation. Journal of Biotechnology, 99: 259-278.

Geng C N, Zhu Y G, Hu Y, Williams P N, Meharg A A, 2006. Arsenate causes differential acute toxicity to two P-deprived genotypes of rice seedlings (Oryza sativa L.). Plant and Soil, 270: 297-306.

Geng C N, Zhu Y G, Liu W J, Smith S E, 2005. Arsenate uptake and translocation in seedlings of two genotypes of rice is affected by external phosphate concentrations. Aquatic Botany, 83: 321-331.

Heikens, 2006. Arsenic contamination of irrigation water, soil and crops in Bangladesh: Risk implications for sustainable agriculture and food safety in Asia. Bangkok: Rap Publication. $1-46$.

Hewitt E J, 1966. Sand and water culture methods used in the study of plant nutrition (2nd ed.). Technical communication no. 22. Commonwealth Agriculture Bureau, Farnham Royal, UK.

Jankong P, Visoottiviseth P, Khokiattiwong S, 2007. Enhanced phytoremediation of arsenic contaminated land. Chemosphere, 68: 1906-1912.

Kobayashi I, Fujiwara S, Shimogawara K, Sakuma C, Shida Y, Kaise T, Usuda H, Tsuzuki M, 2005. High intracellular phosphorus contents exhibit a correlation with arsenate resistance in Chlamydomonas mutants. Plant and Cell Physiology, 46: 489-496.

Lee D A, Chen A, Schroeder J I, 2003. ars1, an Arabidopsis mutant exhibiting increased tolerance to arsenate and increased phosphate uptake. The Plant Journal, 35: 637-646.

Lee R B, 1982. Selectivity and kinetics of ion uptake by barley plants following nutrient deficiency. Annals of Botany, 50: 429-449.

Liu W J, Zhu Y G, Smith F A, Smith S E, 2004. Do phosphorus nutrition and iron plaque alter arsenate (As) uptake by rice seedlings in hydroponic culture? New Phytologist, 162: 481-488.

Meharg A A, Macnair M R, 1992. Suppression of the high affinity phosphate uptake system: a mechanism of arsenate tolerance in Holcus lanatus. Journal of Experimental Botany, 43: 519-524.

Meharg A A, Macnair M R, 1994. Relationship between plant phosphorus status and the kinetics of arsenate influx in clones of Deschampsia cespitosa (L.) Beauv that differ in their tolerance to arsenate. Plant and Soil, 162: 99-106.

Rosa G D L, Parsons J G, Martinez-Martinez A, Peralta-Videa J R, Gardea-Torresdey J L, 2006. Spectroscopic study of the impact of arsenic speciation on arsenic/phosphorus uptake and plant growth in tumbleweed (Salsola kali). Environmental Science and Technology, 40: 1991-1996.

Runge-Metzger A, 1995. Closing the cycle: obstacles to efficient $P$ management for improved global security. In: Phosphorus in the Global Environment (Tiessen H, ed.). Chichester, UK: John Wiley and Sons Ltd. 27-42.

Schachtman D P, Shin R, 2007. Nutrient sensing and signaling: NPKS. Annual Review of Plant Biology, 58: 47-69.

Singh N, Ma L Q, 2006. Arsenic speciation, and arsenic and phosphate distribution in arsenic hyperaccumulator Pteris vittata $\mathrm{L}$. and non-hyperaccumulator Pteris ensiformis L. Environmental Pollution, 141: 238-246.

Smith E, Naidu R, Alston A M, 2002. Chemistry of arsenic in soils: II. Effect of phosphorus, sodium and calcium on arsenic sorption. Journal of Environmental Quality, 31: 
557-563.

Tao S S H, Bolger P M, 1998. Dietary arsenic intakes in the United States: FDA total diet study, September 1991December 1996. Food Additives and Contaminants, 16(11): 465-472.

Ullrich-Eberius C L, Sanz A, Novacky A J, 1989. Evaluation of arsenate- and vanadate-associated changes of electrical membrane potential and phosphate transport in Lemna gibba Gl. Journal of Experimental Botany, 40: 119-128.

Vance C P, Uhde-Stone C, Allan D L, 2003. Phosphorus acquisition and use: critical adaptations by plants for securing a nonrenewable resource. New Phytologist, 157: 423-447.

von Uexkll H R, Mutert E, 1995. Global extent, development and economic impact of acid soils. Plant and Soil, 171: 1-15.

Wang J R, Zhao F J, Meharg A A, Raab A, Feldmann J, McGrath
S P, 2002. Mechanism of arsenic hyperaccumulation in Pteris vittata. Uptake kinetics, Interactions with phosphate, and arsenic speciation. Plant Physiology, 130: 1552-1561.

Williams P N, Islam M R, Adomako E E, Raab A, Hossain S A, Zhu Y G, Feldmann J, Meharg A A, 2006. Increase in rice grain arsenic for regions of Bangladesh irrigating paddies with elevated arsenic in groundwaters. Environmental Science and Technology, 40: 4903-4908.

Williams P N, Price A H, Raab A, Hossain S A, Feldmann J, Meharg A A, 2005. Variation in arsenic speciation and concentration in paddy rice related to dietary exposure. Environmental Science and Technology, 39: 5531-5540.

Zhao F J, Dunham S J, McGrath S P, 2002. Arsenic hyperaccumulation by different fern species. New Phytologist, 156: 27-31. 